\title{
Sammlung Bsp̈jhen
}

\section{(5ejdidte Jaraels}

bis auf bie griedilifge Zeit

\author{
Bon \\ Lic. Dr. I. Benzinger
}

3weite, verbeiferte $\mathfrak{A}$ uflage

Reuðrưf

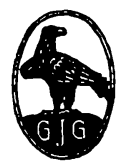

Berlin und Reipzig

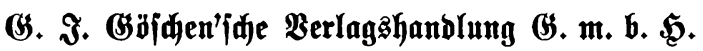




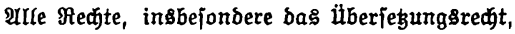
von ber Berlagşandiung vorbehalten.

Spamerja) Bubbrutererei in Reipzig 